\title{
AN ANALYSIS ON POLITENESS STRATEGIES USED BY TEACHERS AND STUDENTS AT SCHOOL OF FOREIGN LANGUAGES, THAI NGUYEN UNIVERSITY
}

\author{
Bui Thi Huong Giang ${ }^{*}$, Dam Thi Quynh ${ }^{2}$, Nguyen Duong $\mathrm{Ha}^{3}$ \\ ${ }^{I}$ Department of International Cooperation - TNU, ${ }^{2}$ ICO Company, \\ ${ }^{3} \mathrm{TNU}$ - School of Foreign Languages
}

\section{SUMMARY}

The study was conducted to analyze the politeness strategies used by teachers and students in English classes at School of Foreign Languages, Thai Nguyen University. The research described what types of politeness strategies used by teachers and what types of politeness strategies used by students in English classes. This research was qualitative descriptive and quantitative research. The subjects of the study were two English teachers and forty-six students of two English classes at School of Foreign Languages, Thai Nguyen University. To collect the data, recording video and interviewing were used. Brown \& Levinson's and Q. Nguyen's theory of politeness strategies were used in this research. The result of this research showed that there were four main strategies employed by the teachers and students in English classes at School of Foreign Languages, Thai Nguyen University. They were bald on record, positive politeness, negative politeness, and off record strategy, in which positive politeness strategy dominated the politeness strategies used by teachers as well as students during the teaching and learning process.

Keywords: politeness strategy; bald on record; positive politeness; negative politeness; off record; Thai Nguyen University

Received: 13/01/2020; Revised: 18/3/2020; Published: 23/3/2020

\section{PHÂN TÍCH CÁC CHIẾN LƯợC LỊCH SỰ ĐƯợC SỬ DỰG CỦA GIÁO VIÊN VÀ SINH VIÊN TẠI KHOA NGOẠI NGŨ், ĐẠI HỌC THÁI NGUYÊN}

\author{
Bùi Thị Hương Giang ${ }^{1 *}$, Đàm Thị Quỳnh ${ }^{2}$, Nguyễn Dương Hà ${ }^{3}$ \\ ${ }^{1}$ Ban Hợp tác Quốc tế - ĐH Thái Nguyên, ${ }^{2}$ Công ty ICO, Khoa Ngoại ngũ - ĐH Thái Nguyên
}

\section{TÓM TẮT}

Nghiên cứu được thực hiện để phân tích các chiến lược lịch sự được sử dụng bởi các giáo viên và sinh viên thuộc Khoa Ngoại ngữ - Đại học Thái Nguyên. Nghiên cứu mô tả các loại chiến lược lịch sự được sử dụng bởi giáo viên và các loại chiến lược lịch sự được sử dụng bởi sinh viên trong các lớp học tiếng Anh. Nghiên cứu này là nghiên cứu mô tả định tính và định lượng. Đối tượng nghiên cứu là hai giáo viên tiếng Anh và bốn mươi sáu sinh viên của hai lớp tiếng Anh tại Khoa Ngoại ngữ - Đại học Thái Nguyên. Để thu thập dữ liệu, nhà nghiên cứu đã sự dụng cách ghi lại video và phỏng vấn. Lý thuyêt về chiến lược lịch sự của Brown \& Levinson và $Q$. Nguyễn cũng được sử dụng trong nghiên cứu này. Kết quả của nghiên cứu cho thấy có bốn chiến lược chính được sử dụng bởi các giáo viên và sinh viên trong các lớp học tiếng Anh tại Khoa Ngoại ngữ - Đại học Thái Nguyên, đó là chiến lược lịch sự công khai, lịch sự dương tính, lịch sự âm tính và chiến lược lịch sự không công khai, trong đó, chiến lược lịch sự dương tính chi phối việc sử dụng chiến lược lịch sự của giáo viên cũng như học sinh trong quá trình giảng dạy.

Từ khóa: chiến luợc lịch sư; chiến luợc lịch sự công khai; lịch sư duơng tính; lịch sụ âm tính; chiến lược lịch sư không công khai; Đại học Thái Nguyên

Ngày nhận bài: 13/01/2020; Ngày hoàn thiện: 18/3/2020; Ngày đăng: 23/3/2020 


\section{Introduction}

Over the last four decades, together with many other aspects of pragmatics, politeness is one of the most popular areas. Studies on politeness have been recently conducted worldwide especially in the area of sociolinguistics and anthropolinguistics. Other settings of communication, such as education and classroom setting, also highlight the important roles of politeness. Maintaining politeness in the class is a good strategy to reach effective classroom interaction.

In Vietnam, politeness studies which explore the teachers and students' politeness strategies are still limited, especially politeness strategies used by teachers and students in university. Therefore, with a desire to have a further insight into a major problem the writer develops the research entitled "An analysis on politeness strategies used by teachers and students in English classes at School of Foreign Languages, Thai Nguyen University (SFL-TNU)" to investigate and emphasize the vital role of politeness strategies in education in general and the use of politeness strategies by English university teachers and students in the classroom context in particular.

\section{Literature review}

Politeness is one of the most important aspects of human communication. Recently, politeness has been considered as a pragmatic phenomenon, requiring a great deal of research to improve human's interaction and therefore reinforced the study of language in its social context. Although the essence of politeness is popular in all cultures, it is expressed differently in different cultures. Most scholars agree that politeness is used to avoid conflicts. Lakoff [1] specifies, "Politeness is developed by societies in order to reduce friction in personal interaction," thus indirectly claiming politeness universality. Similarly, Leech [2] defines that politeness is "strategic conflict avoidance" which "can be measured in terms of the degree of effort put into the avoidance of a conflict situation." Brown \& Levinson [3] ascertain the politeness "as a complex system for softening face threats." It can be summarized that politeness is the use of an appropriate word or phrase in the appropriate context that is determined by the rules that are prevalent in society. One of the most important contributions to the study is Grice's [4] Cooperative Principle (CP) and his Maxims of Conversation. Grice proposed four conversation Maxims, including maxim of quantity, quality, relevance and manner. Although Grice's maxims did not address the notion of politeness directly, they became the bases of subsequent studies investigating politeness. Lakoff is the first person who developed Grice's idea into a theory of politeness built on the Cooperative principle. Lakoff [1] explains that the politeness rules consist of Not imposing (used in a formal context); Giving options (used in an informal context); and Making a feel good - Being friendly (used in an intimate circle). These three rules are applicable depending on the type of politeness required as understood by the speaker. The choice of any of these politeness rules will depend on the speaker's assessment of the situation and interpersonal relationships.

Leech [2] also adopts Grice's conversational maxims and analyzed politeness in terms of maxims within a pragmatic framework. Leech explains that politeness concerns a relationship between two participants, but speakers also show politeness to third parties who may or may not be present in the speech situation. There are six maxims of the politeness principle that are used to explain the relationship between sense and force in daily conversation, namely Tact maxim, Generosity maxim, Approbation maxim, Modesty maxim, Agreement maxim and Sympathy maxim.

By and large, the most influential of all views has been Brown \& Levinson's face-saving 
approach to politeness [3]. Brown \& Levinson's politeness model is founded on the notions of face. According to them, all the speakers of a language have both a positive and a negative face. Positive face is the desire to be liked, appreciated, approved, etc. Negative face is the desire not to be imposed upon, intruded, or otherwise put upon. Brown \& Levinson [3] outline four main types of politeness strategies including bald on-record, positive politeness, negative politeness, and off-record (indirect). These main types of politeness are used to focus on various strategies used by a variety of people in their interactional behavior to satisfy specific wants of face.

In Vietnam, showing concern, in-group membership and closeness among interactants in face-to-face conversations are widely resorted to and always considered more polite. For this reason, although highly appreciating Brown \& Levinson's theory of politeness, Q. Nguyen [5] raises his doubt of its universal validity, especially of numbering two and three for positive and negative politeness. To sum up, "politeness" in communication is viewed from different angles. Grice, Lakoff, Leech, and Brown \& Levinson are the persons who laid the foundation for this domain. In comparison with Grice's, Lakoff's and Leech's approaches, the approach by Brown \& Levinson is more practical and universal.

\section{Methodology}

The participants of this study were 2 teachers of English and 46 first-year students from two English classes at School of Foreign Languages, Thai Nguyen University. Their English proficiency ranged from A2 to B1 (based on the Common Vietnamese Framework of Reference). Most of them have studied English at least for 3 - 5 years. Therefore, they are easy to adapt with new environment and knowledge. However, they have not yet been proficient in special English, such as the notion of pragmatic, discourse analysis or politeness strategy, etc. In the current study, the criterion of importance is learners' general language proficiency to ensure their homogeneity. In selecting the participant, the researcher used purposive sampling technique by choosing two teachers of English and 46 first-year students. This sample size is supported by a rule of thumb, i.e., the minimum number of participants is no less than 30 [6]. According to Patton [7], purposeful sampling is a technique widely used in qualitative research to identify and select information rich cases for the most effective use of limited resources.

Data for the present study, which are descriptive in nature, were collected by means of video recorder and a set of interview questions. The recording was done four times by observing the utterances used by 02 teachers and 46 first year students during the English teaching process. Interviews were used to get information about the interaction between teachers and students during the process of learning English. The researcher takes the result of interview to reinforce the research finding obtained from the video record.

\section{Research findings}

This section consists of two parts. The first part describes the findings of video recording for the types of politeness strategies used by teachers and students in English classes. The second part describes the findings of interviews for teachers and students. The researcher did the video recording first and then interviewed teachers and students. After the data of interview was collected, checking trustworthiness of data was done by comparing data interview and data video recording. 


\subsection{Video recording findings}

4.1.1. The politeness strategies used by teachers during the teaching process in English classes

From the analysis of four conversations, the frequency of the use of politeness strategy by teachers in uttering politeness strategies during teaching process will be illustrated in Table 1 .

As drawn in Table 1, there were 110 utterances of politeness strategies used by the teacher during the teaching process in English classes. From the total number of 110 utterances, the researcher found 61 utterances that used Positive politeness strategy, 24 utterances used Bald on record strategy, 19 utterances used Negative politeness strategy and 06 utterances used Off record strategy (accounted for 55.45\%, 21.28\%, 17.27\% and
$5.45 \%$ respectively). The use of Politeness strategy was dominated by positive politeness strategy. Overall, the teachers applied most of Positive politeness strategy in their teaching process. It was observed that positive politeness strategy was employed more frequently than other politeness strategies with $55.45 \%$. Bald on record strategy came to second with $21.82 \%$. The Negative politeness and the Off record strategy accounted for $17.27 \%$ and $5.45 \%$ alternately.

4.1.2. The politeness strategies used by students during the learning process in English classes

Table 2 displays the politeness strategies used by students during the learning process that was collected from the recorded conversations.

Table 1. Frequency of the use of politeness strategies by teachers in uttering politeness strategies during the teaching process

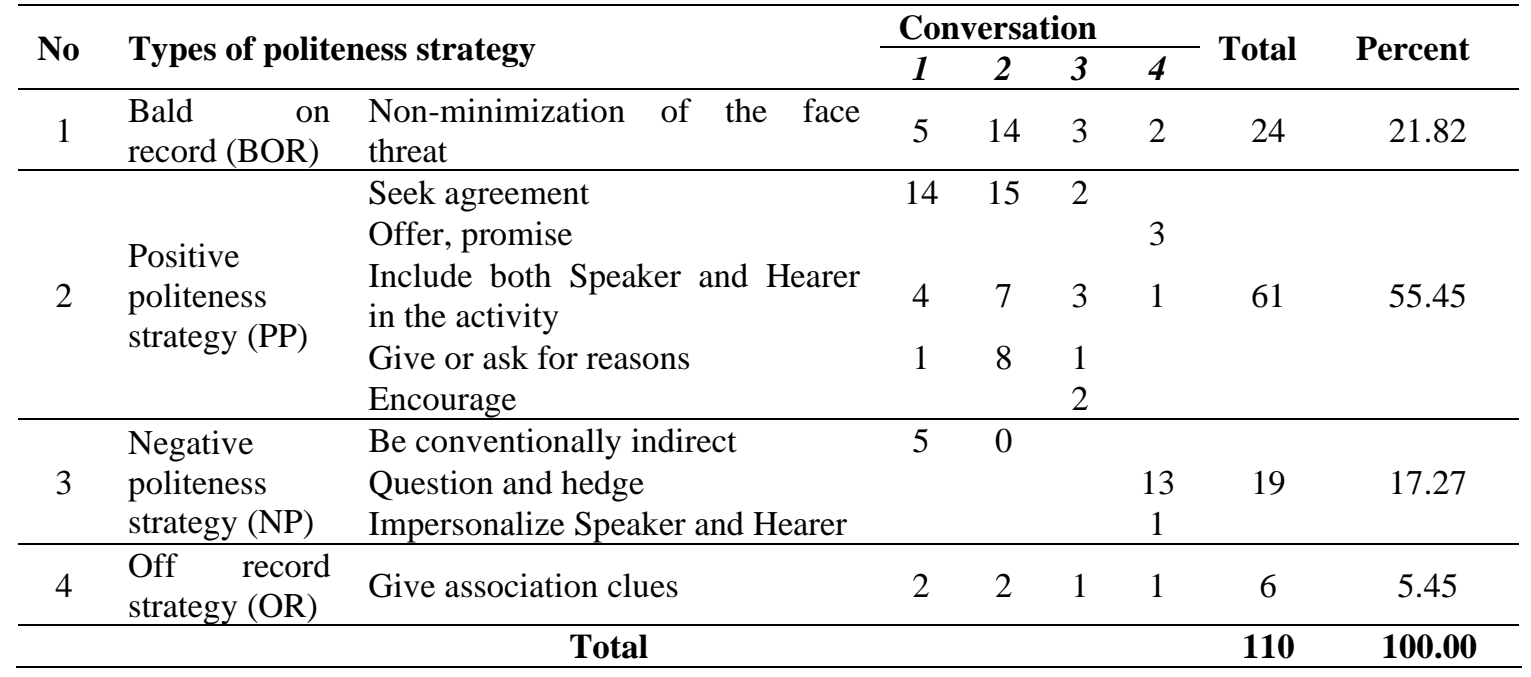

Table 2. Frequency of the use of politeness strategies by students in uttering politeness strategies during learning process

\begin{tabular}{|c|c|c|c|c|c|c|c|c|}
\hline \multirow{2}{*}{ No } & \multirow{2}{*}{\multicolumn{2}{|c|}{ Types of politeness strategy }} & \multicolumn{4}{|c|}{ Conversation } & \multirow{2}{*}{ Total } & \multirow{2}{*}{ Percent } \\
\hline & & & 1 & 2 & 3 & 4 & & \\
\hline \multirow{3}{*}{1} & \multirow{3}{*}{$\begin{array}{l}\text { Positive } \\
\text { politeness } \\
\text { strategy (PP) }\end{array}$} & Seek agreement & 4 & 12 & & 10 & \multirow{3}{*}{34} & \multirow{3}{*}{97.00} \\
\hline & & Give or ask for reasons & 1 & 3 & 2 & & & \\
\hline & & $\begin{array}{l}\text { Include both Speaker and } \\
\text { Hearer in the activity }\end{array}$ & & & & 2 & & \\
\hline 2 & $\begin{array}{l}\text { Negative } \\
\text { politeness } \\
\text { strategy (NP) }\end{array}$ & Question and hedge & & 1 & & & 1 & 3.00 \\
\hline 3 & $\begin{array}{l}\text { Bald on record } \\
\text { (BOR) }\end{array}$ & $\begin{array}{l}\text { Non-minimization of the } \\
\text { face threat }\end{array}$ & 0 & 0 & 0 & 0 & 0 & 0.00 \\
\hline 4 & $\begin{array}{l}\text { Off record } \\
\text { strategy (OR) }\end{array}$ & Give association clues & 0 & 0 & 0 & 0 & 0 & 0.00 \\
\hline Total & & & 5 & 16 & 2 & 12 & 35 & $\mathbf{1 0 0 . 0 0}$ \\
\hline
\end{tabular}

http://jst.tnu.edu.vn; Email: jst@tnu.edu.vn 
According to Table 2, there were 35 utterances of politeness strategies used by the students during learning process in English class. The findings clearly depicted that the students applied most of Positive politeness strategy in learning process with $97 \%$ of total. The strategy of Seek agreement is in the highest rank with 26 data out of the 34 data. The Negative politeness strategy only represents $3 \%$ and no records found with Bald on record and Off record strategy.

\subsection{Interview findings}

With the aim of collecting further information to reinforce the result of video recording analysis, an interview was employed to investigate the teachers and students' opinions on politeness strategies used in English class. The researcher interviewed 02 teachers and 05 students from two classes. The number of participants selected for the interview was determined based on resource availability and the study objectives, ie., at least six for qualitative research [8]. An interview questionnaire containing questions on major themes of politeness strategies was prepared. After each interview, the researcher transcribed the recorded interview.

\subsubsection{Interview the teachers}

+ Description of context

Researcher : R

Teacher $1 \quad$ : T1

Teacher $2 \quad:$ T2

The researcher interviewed 2 teachers and the content of the interview was related to the politeness strategies. The first question was to focus on the definition of "politeness".

$\mathrm{R}$ : In your opinion, what is politeness?

T1: I think politeness is the way we behave respectfully.

T2: I think politeness is behaving in a way that is socially correct and shows respect for other people's feelings.
The second question was "How can people keep polite in communication?" To answer the question, two teachers gave a lot of ways to keep polite in communication, such as listening and be understanding; avoiding negative words - instead using positive words in a negative form; saying the magic word (for example, using the magic word "Sorry" to interrupt, to apologize, to show you do not understand or to disagree), etc.

The last questions of the interview which the researcher used to ask the teachers was about politeness strategies that they often used during the teaching process

$\mathrm{R}$ : What politeness strategies do you think you often use in English class during teaching process?

T1: I think... It is positive politeness strategy.

T2: In my opinion, ah... It's positive politeness strategy.

After the interview, the researcher found that teachers often used positive politeness strategy in English classes during teaching process.

\subsubsection{Interview the students}

The researcher randomly interviewed 5 students from 2 English classes. The questions of the interview for students and steps carried out were similar to the interview for teachers.

R: What politeness strategies do you think you or students often use in English class during learning process?

St1: In my opinion, ah... It's positive politeness strategy

St2: I think, ah... the first and the last one will be used not often as the second and the last one.

St3: In my opinion, the positive politeness strategy will be used usually in class.

St4: I think, ah... we should use the first and the second one (the bald on record and the positive strategy).

St5: I think, ah... Both bald on record and positive politeness strategy. 
The results of the students' interview showed that three out of five students had the answers that they used Positive politeness strategy during learning process and two last ones had answers that they used Bald on record and Positive politeness strategy during learning process.

To sum up, the findings from video recording clearly illustrated that the teachers applied most of Positive strategy in teaching process and students used most of positive politeness strategy in learning. The findings from teachers and students' interviews also revealed that most of teachers and students chose Positive politeness and Bald on strategy in English classes. It means that the findings which researcher found by video recording coincide with the findings of the interviews. Positive politeness strategy was used by teachers and students in English classes more frequently than other politeness strategies.

\section{Discussion}

Firstly, the strategy of positive politeness is in the highest rank with 61 data out of the 110 data. This seems to suggest that teachers tend to employ more positive politeness in order to be closer to their students (sense of solidarity) so that they are more likely to reach the final agreement. The teachers use positive politeness strategies because they can satisfy students' positive face, to some respect [3]. In the second rank, there is a strategy of "bald on record" which have 24 data which is accounted for $21.28 \%$. Bald on record is related with directness which is employed by speaker who has higher authority than the hearer. Thus, bald on record is commonly uttered by speaker who has higher authority or more powerful than hearer. The use of bald on record strategy is reflected when the teachers utter command to the students. By using this strategy, the addressee is possible to catch the speakers' meaning, so misunderstanding can be avoided [3]. Therefore, the teachers often use this strategy to do their instruction.
Secondly, from the total number of 35 utterances used by students, 34 utterances used positive politeness strategies, and only one utterance used negative politeness strategy. The use of politeness strategy was dominated by positive politeness strategy which was accounted for $97 \%$. This strategy is usually seen in groups of friends or where people given social situation know each other fairly well. Yule [9] says that positive politeness strategy intends a supplicant to draw general purpose and even friendship. The use of positive politeness is seen from the intimacy between the speaker and the listener. The positive politeness utterance describes a high risk for a pain from rejection. Thus, it perhaps can be formed by a courtesy as the speaker's effort to recognize a face of a listener. From doing this strategy, the students can give a respect to the teachers and minimize the face threatening acts by assuring the teachers that they consider them to be of a same kind; they like them and want their wants.

Overall, the findings of this research are consistent with many previous studies. The biggest similarity is that all of the studies utilized qualitative research method. The framework theoretical is based on Brown \& Levinson's theory [3] of politeness. The data were basically collected through observation, video recording or audio recording, interview. Both studies used the framework theoretical proposed by Brown \& Levinson's [3] and Q. Nguyen's [5] theory of politeness. The major method employed is quantitative and qualitative methods. The findings show that positive politeness strategy is used more frequently than other strategies. The findings from these studies revealed that students used different kinds of politeness strategies in class, including positive and negative politeness strategies. However, the positive strategy is frequently used positive strategies in class as opportunity for asynchronous interaction in response to their teachers and peers. 
The result of this study was in contrast with the studies conducted by Kurniatin [10] and Ayu [11]. The results of these studied showed that four types of politeness strategies, namely bald on record, positive politeness, negative politeness and off record employed by lecturers/teachers and students in classes. The differences in the results may be attributed to the collective effect of different factors including the research context, participant, age, gender and culture. In the study by Kurniatin [10], only one teacher took part in the study and students were from 9 classes. Moreover, the research place is in Indonesia. Therefore, these factors make the differences in the results.

The findings of the study show that there are four main types of politeness employed by the teachers and students in English classes at SFL-TNU. They are bald on record, positive politeness, negative politeness and off record strategy, in which positive politeness strategy is used more frequently. These findings are in line with some other studies and in contrast with others. However, these findings are in agreement with researcher's culture context as Q. Nguyen [5] has explained, while negative polite strategies seem to be preferred in Western countries, positive politeness strategies tend to be more commonly used in non-western communities including Vietnam.

\section{Conclusion and recommendations}

The study aims at identifying the importance of politeness in communication. It investigates 4 politeness strategies, namely bald on record strategy, positive politeness strategy, negative politeness strategy and off record strategy and examines their frequency of occurrence by teachers and students using uttering politeness strategy during teaching process which is based on the theoretical background of politeness proposed by Brown \& Levinson [3] and Q. Nguyen [5]. Based on the research findings and discussions, the result of this research shows two important points as follows. Regarding to the application of politeness strategies used by teachers, the findings show that all politeness strategies can be found in the teachers' utterances, in which, the positive politeness strategy noted as the high rank (61 out of 110 utterances). Meanwhile, off record strategy is in the lowest rank. The researcher found 35 utterances containing politeness strategy used by students. There are 34 utterances of positive politeness strategy, and 01 utterance of negative politeness strategy. The data show that the students preferred positive politeness strategy to other strategies in conducting communication with the teacher during teaching process. Teachers should use positive politeness especially to make the students feel good about themselves, their interests or possessions and also to make good interaction between teachers and students while teaching interaction between teachers and students while teaching and learning in order to encourage students' motivation to learn. Negative politeness should be used to avoid imposition to the students in learning, bald on-record should be used when efficiency is necessary, task-oriented, and when information needs to be shared quickly, as the reasons of the teacher and the students felt that they had a close relationship.

This research can be an additional reference for the English student especially for linguistic students. It is suggested for the English students who take linguistic concentration for they have to learn more about pragmatics especially politeness strategy. The students are supposed to learn pragmatics seriously. It is important because pragmatic is a study which learns about the meaning behind the sentence. This research just focuses on what kinds of politeness strategies used by teachers and first year students in English classes at SFL-TNU. This study can lead other researchers to conduct 
research on politeness strategies in other form of literary works, such as poetry and drama in the purpose of enriching the discourse studies. It is also hoped that the study on politeness involves language other than English; so, it can broaden the knowledge in applying linguistic aspects in various languages. Besides, due to time and space constraints, the data collection taken from only two English teachers and 46 students from two English classes is not large enough to assure a complete generalization.

\section{REFERENCES}

[1]. R. Lakoff, Language and Woman's Place. New York: Harper \& Row, 1975.

[2]. G. N. Leech, Principles of Pragmatics. London: Longman, 1983.

[3]. P. Brown and S. Levinson, Politeness: Some Universal in Language Usage. Cambridge University Press, 1987.
[4]. P. Grice, "Logic and Conversation," in Syntax and Semantics, P. Cole (eds), vol. 3, pp 41-58, 1975.

[5]. Q. Nguyen, Intracultural and Cross-culture Communication. VNU Press, 2003.

[6]. R.V. Hogg and E. Tanis, Probability and Statistical Inference, $8^{\text {th }}$ ed. Pearson, 2009.

[7]. M. Q. Patton, Qualitative Research and Evaluation Methods, $3^{\text {rd }}$ ed. Thousand Oaks, CA: Sage Publications, 2002.

[8]. N. K. Denzin and Y.S. Lincoln, Handbook of Qualitative Research, $2^{\text {nd }}$ ed. Thousand Oaks, CA: Sage, 1994.

[9]. G. Yule, Pragmatics. Oxford: Oxford University Press, 1996.

[10]. Kurniatin, "An Analysis of Politeness Strategies used by Teacher and Students in English Class at MTs NU Assalam Kudus," Sarjana Thesis, Institute of Surakarta (IAIN Surakarta), 2017.

[11]. G. Ayu, "An analysis on politeness strategies employed by lecturers in speaking class," Sarjana Thesis, Ar-Raniry State Islamic University, 2018. 